\title{
Pengaruh Berbagai Konsentrasi Pupuk Organik Cair (POC) Azolla pinnata dan Jarak Tanam Terhadap Pertumbuhan Dan Hasil Tanaman Sawi Hijau (Brassica juncea L.)
}

\author{
(Effect of Various Concentrations of Liquid Organic Fertilizer Azolla \\ pinnata andPlanting Distance on Growth and Yield of Green Mustard \\ (Brassica juncea L.)
}

\author{
Andi Purnama MS*, Jenal Mutakin, dan Hanny Hidayati Nafia'ah** \\ Program Studi Agroteknologi, Fakultas Pertanian Universitas Garut. \\ Jalan Raya Samarang Nomor 52A, Garut \\ Email : andipurnama791@gmail.com
}

\begin{abstract}
Abstrak
Produksi sawi hijau di Indonesia masih rendah karena beberapa alasan, salah satu jalan keluarnya adalah pemberian pupuk organik. Tujuan penilitian ini adalah untuk mengetahui konsentrasi pupuk organik cair Azolla dan jarak tanam yang tepat pada pertumbuhan dan hasil tanaman sawi hijau. Percobaan dilaksanakan di Lahan Percobaan BPBP (Balai Pengembangan Benih Palawija) Sub Unit Karangpawitan Desa Situjaya, Kecamatan Karangpawitan, Kabupaten Garut yang dilaksanakan pada bulan April sampai Mei 2021. Metode penelitian yang digunakan adalah metode eksperimental dengan menggunakan Rancangan Acak Kelompok (RAK) pola faktorial 4 x 4 yang diulang sebanyak dua kali. Faktor pengamatan pertama yang dilakukan yaitu berbagai konsentrasi POC Azolla pinnata yang terdiri empattaraf, yaitu : Faktor I : Konsentrasi POC Azolla pinnata $(\mathrm{P})$, terdiri atas 4 taraf, yaitu: $\mathrm{p}_{1}=0 \mathrm{ml} / \mathrm{l}$ (kontrol), $\mathrm{p}_{2}=5 \mathrm{ml} / \mathrm{l}, \mathrm{p}_{3}=10 \mathrm{ml} / \mathrm{l}$, dan $\mathrm{p}_{4}=15 \mathrm{ml} / \mathrm{l}$. Faktor keduaadalah jarak tanam yang digunakan $(\mathrm{J})$, terdiri atas 4 taraf, yaitu $: \mathrm{j}_{1}=10 \mathrm{~cm} \times 10 \mathrm{~cm}, \mathrm{j}_{2}=10 \mathrm{~cm} \times 15 \mathrm{~cm}, \mathrm{j}_{3}=10 \mathrm{~cm} \times 20 \mathrm{~cm}$, dan $\mathrm{j}_{4}=10 \mathrm{~cm} \times 25 \mathrm{~cm}$. Hasil penelitianmenunjukkan tidak terjadi interaksi antara berbagai konsentrasi POC Azolla dan jarak tanam terhadap pertumbuhan dan hasil sawi hijau. Secara mandiri konsentrasiPOC Azolla $15 \mathrm{ml} / 1$ dan jarak tanam $10 \mathrm{~cm}$ x $25 \mathrm{~cm}$ dapat meningkatkan tinggi tanaman pada umur 28 HST dan bobot segar tanaman per plot.
\end{abstract}

Kata kunci: jarak tanam, POC Azolla, sawi hijau.

Abstract
Green mustard production in Indonesia is still low for several reasons, one of the
solutions is the application of organic fertilizer. The purpose of this study was to
determine the concentration of Azolla liquid organic fertilizer and the proper spacing on
the growth and yield of mustard greens. The experiment was carried out at the BPBP
Experimental Land (Balai Seed Development Palawija) Sub Unit Karangpawitan
Situjaya Village, Karangpawitan District, Garut Regency which was carried out from
April to May 2021. The research method used was an experimental method using a
factorial 4 randomized block design (RAK) $x 4$ which is repeated twice. The first
observation factor was various concentrations of Azolla pinnata POC which consisted of


four levels, namely: Factor I: Azolla pinnata POC concentration (P), consisted of 4 levels, namely: $p 1=0 \mathrm{ml} / \mathrm{l}$ (control), $p 2=5 \mathrm{ml} / \mathrm{l}, \mathrm{p} 3=10 \mathrm{ml} /$, and $\mathrm{p} 4=15 \mathrm{ml} / \mathrm{l}$. The second factor is the spacing used (J), consisting of 4 levels, namely: $j 1=10 \mathrm{~cm} \times 10 \mathrm{~cm}$, $j 2=10 \mathrm{~cm} \times 15 \mathrm{~cm}, j 3=10 \mathrm{~cm} \times 20 \mathrm{~cm}$, and j4 =10 cm $\times 25 \mathrm{~cm}$. The results showed that there was no interaction between various concentrations of POC Azolla and plant spacing on the growth and yield of mustard greens. Independently, the concentration of $P O C$ Azolla $15 \mathrm{ml} / \mathrm{l}$ and spacing of $10 \mathrm{~cm} \times 25 \mathrm{~cm}$ increased plant height at 28 DAP and plant fresh weight per plot.

Keywords: spacing, POC Azolla, mustard greens.

\section{Pendahuluan}

Sawi hijau merupakan salah satu tanaman sayur yang paling banyakdipasarkan dan digemari oleh masyarakat karena memiliki prospek, potensi, dan gizi pangan yang cukup tinggi. Potensi hasil sawi hijau dapat mencapai 20-30 ton/ha (Haryantodkk, 2007), sedangkan rata-rata hasil sawi hijau di Indonesia hanya 11,43-12,04 ton/ha (BPS, 2021), makadiperlukan salah satu langkah untuk meningkatkan dan membuat stabil produksi sawi hijau dengan memberikan teknik produksi yang efektif dan efisien.

Upaya yang dapat dilakukan untukmeningkatkan produksi sawidiantaranya yaitu melalui efisiensi pemupukan. Efisiensi penggunaan pupuk dapat ditempuh melalui prinsip tepat jenis, tepat dosis, tepat cara, tepat waktu aplikasi, dan berimbang sesuai kebutuhan tanaman(Syafruddin, dkk, 2009). Kesalahandalam penggunaan pupuk dapat mengakibatkan biaya produksi meningkat tetapi hasil yang diperolehtidak seperti yang diharapkan (Gunawan, 2013).

Akibat dari permasalahan tersebutperlu dicarikan jalan keluar untuk mencukupi semakin banyaknya kebutuhan akan sawi hijau di Indonesia. Salah satu jalan keluar adalah pemberian pupuk organik cairyang ramah lingkungan dan mudah didapatkan di lingkungan petani.

Penerapan jarak tanam juga merupakan salah satu kunci yang bisamemengaruhi populasi tanaman dalam budidaya tanaman. Apabila populasi terlalu sedikit atau terlalu banyak akan memengaruhi hasil produksi baik karena terlalusedikitnya jumlah tanaman per hektarataupun kompetisi antar tanaman.Menurut Haryadi (1988), kerapatantanaman mempengaruhi penampilan dan produksi tanaman, umumnyaproduksi per satuan luas yang tinggi di dapat dari populasi tertentu yang dapat memanfaatkan penggunaancahaya secara maksimal.

\section{Metodologi}

Percobaan dilaksanakan di Lahan Percobaan BPBP (BalaiPengembangan Benih Palawija) Sub Unit Karangpawitan Desa Situjaya,Kecamatan Karangpawitan,Kabupaten Garut yang terletak pada ketinggian 715 mdpl (data dari KantorBPBP Karangpawitan, Garut). Percobaan dilaksanakan pada bulanApril sampai Mei 2021. Suhu harian rata-rata $30^{\circ}-34^{\circ} \mathrm{C}$. Data curah hujanrata-rata $1879 \mathrm{~mm}$ pertahunberdasarkan data yang diperoleh dari Kantor BPBP Karangpawitan, Kabupaten Garut pada tahun 2020.Data curah hujan 
diklasifikasikan ke dalam tipe $\mathrm{C}$ atau agak basah.

Metode penelitian yang digunakan adalah metode eksperimental dengan menggunakan Rancangan Acak Kelompok (RAK) pola faktorial 4 x 4 yang diulang sebanyak dua kali.Faktor pengamatan pertama yangdilakukan yaitu berbagai konsentrasi POC Azolla pinnata yang terdiri empat taraf, yaitu : Faktor I : Konsentrasi POC Azolla pinnata $(\mathrm{P})$, terdiri atas 4 taraf, yaitu: $\mathrm{p}_{1}=0 \mathrm{ml} / \mathrm{l}$ (kontrol), $\mathrm{p}_{2}=5 \mathrm{ml} / \mathrm{l}, \mathrm{p}_{3}=10 \mathrm{ml} / \mathrm{l} \mathrm{p}_{4}=$ $15 \mathrm{ml} / \mathrm{l}$. Sumber : Akhmad (2018). Faktor kedua adalah jarak tanamyangdigunakan (J), terdiri atas 4 taraf, yaitu: $\mathrm{j}_{1}=10 \mathrm{~cm} \times 10 \mathrm{~cm}, \mathrm{j}_{2}=10 \mathrm{~cm} \times 15 \mathrm{~cm}, \mathrm{j}_{3}=10 \mathrm{~cm} \times 20 \mathrm{~cm}, \mathrm{j}_{4}$ $=10 \mathrm{~cm}$ x $25 \mathrm{~cm}$. Sumber : Emilia danImanuel (2012). Untuk mengetahui pengaruh perlakuan yang diuji, digunakan analis varian melaui uji $\mathrm{F}$ dengan model linear yang dikemukakan oleh Warsa dan Cucu (1982) adalah sebagai berikut:

$$
X_{i j k}=\mu+r_{i}+P_{j}+J_{k}+(P J)_{j k}+€_{i j k}
$$

\section{Hasil dan Pembahasan}

\section{Tinggi Tanaman (cm)}

Nilai rata-rata tinggi tanaman dapat dilihat pada Tabel 1 . Hasil analisis ragam menunjukkan tidak terjadi interaksi antara konsentrasi POC Azolla dan jarak tanam terhadap tinggi tanaman sawi hijau, namun secara mandiri terdapat pengaruh yang berbeda nyata, yaitu pada tinggitanaman umur pengamatan 28 HST.

Hasil analisis ragam menunjukkan tidak berbeda nyata pada berbagai taraf perlakuan konsentrasi dan jarak tanam umur 14 dan 21 HST. Kebutuhan unsur hara pada tanaman yang berukuran kecil lebih sedikit dibanding tanaman yang berukuranlebih besar.

Tabel 1. Tinggi Tanaman $(\mathrm{cm})$

\begin{tabular}{llll}
\hline Perlakuan & $14 \mathrm{HST}$ & $21 \mathrm{HST}$ & $28 \mathrm{HST}$ \\
\hline $\mathrm{p}_{1}$ & $14,04 \mathrm{a}$ & $22,54 \mathrm{a}$ & $27,20 \mathrm{a}$ \\
$\mathrm{p}_{2}$ & $14,08 \mathrm{a}$ & $22,76 \mathrm{a}$ & $27,11 \mathrm{a}$ \\
$\mathrm{p}_{3}$ & $14,26 \mathrm{a}$ & $23,20 \mathrm{a}$ & $27,84 \mathrm{a}$ \\
$\mathrm{p}_{4}$ & $14,31 \mathrm{a}$ & $23,16 \mathrm{a}$ & $27,98 \mathrm{~b}$ \\
\hline $\mathrm{j}_{1}$ & $14,15 \mathrm{a}$ & $22,83 \mathrm{a}$ & $27,02 \mathrm{a}$ \\
$\mathrm{j}_{2}$ & $14,15 \mathrm{a}$ & $22,93 \mathrm{a}$ & $27,42 \mathrm{a}$ \\
$\mathrm{j}_{3}$ & $14,02 \mathrm{a}$ & $22,94 \mathrm{a}$ & $27,62 \mathrm{a}$ \\
$\mathrm{j}_{4}$ & $14,37 \mathrm{a}$ & $22,96 \mathrm{a}$ & $28,07 \mathrm{~b}$ \\
\hline
\end{tabular}

Keterangan : Angka rata-rata pada setiap kolom yang ditandai denganhuruf yang sama menunjukkan tidak berbedanyata menurut Uji Lanjut Jarak Berganda Duncan pada taraf5\%.

Menurut Rajiman (2020), pada kondis status tanah sedang, jumlahhara relatif cukup untuk mendukung pertumbuhan dan produksi tanaman, sehingga produktivitas sudah memadai. Produktivitas sedikit akan mengalami kenaikan jika dilakukanpemupukan. 
Menurut Nurlaeny (2015) Tanah bertindak sebagaimedia bagi pertumbuhan berbagai jenis tanaman dan memasoknyadengan berbagai unsur hara yang diperlukan. Status unsur hara yangterkandung dalam ekosistem tanah akan membatasi pertumbuhan tanaman. Akibat dari adanya unsurhara yang cukup pada tanah, sehinggamenyebabkan belum terlihatterjadinya perbedaan dari hasil analisis ragam pada berbagai taraf perlakuan.

Hasil analisis ragam pada umur 28HST terlihat konsentrasi Azolla berbeda nyata pada taraf perlakuan $\mathrm{p}_{1}, \mathrm{p}_{2}$, dan $\mathrm{p}_{3}$ dibandingkan dengan taraf perlakuan $\mathrm{p}_{4}$. Diduga pada umur 28 HST kondisi tanaman yang sudah cukup besar membuat kebutuhanunsur hara tanaman meningkat danterjadi kekurangan pada konsentrasi $\mathrm{p}_{1}, \mathrm{p}_{2}$, dan $\mathrm{p}_{3}$. Penambahan konsentrasiPOC Azolla efektif meningkatkan tinggi tanaman diumur 28 HST. Hal ini terjadi diduga karena POC Azolla dapat memberikan ketersediaan unsurhara terutama nitrogen sehingga tersedia pada awal pertumbuhan vegetatif tanaman, tanaman lebih optimal dalam menyerap unsur tersebut dan memberikan respon yang cepat pada pertumbuhan vegetatifnya.Menurut Dhiya, dkk, (2015) Azolla telah banyak digunakan sebagaipupuk organik karena mengandungnitrogen yang cukup tinggi. Azollabanyak terdapat pada persawahan di Indonesia sehingga cukupmenjanjikan untuk menjadikannya sebagai sumber nitrogen biologis yang berasal dari jasad hayati alami yang bersifat dapat diperbaharui.

Hasil analisis ragam tinggitanaman menunjukkan berbeda nyatapada perlakuan jarak tanam diumur 28 HST. Taraf perlakuan berbeda nyata antara $\mathrm{j}_{1}, \mathrm{j}_{2}$, $\mathrm{j}_{3}$ dibanding taraf perlakuan $\mathrm{j}_{4}$. Diduga perbedaan yang terjadi umur 28 HST karena tanamanmulai membutuhkan unsur hara yanglebih banyak karena ukuran yang bertambah besar. Jarak tanam yang semakin lebar membuat ruang mendapatkan cahaya, kandungan unsur hara tanah, dan udara menjadi lebih leluasa antar tanaman. Hal ini diduga penyebab jarak tanam $\mathrm{j}_{4}$ menjadi lebih tinggi dibanding taraf perlakuan yang lainnya. Pengaturan jarak tanam sangat berpengaruh terhadap pertumbuhan dan hasil tanaman. Jarak tanam ditunjukan untuk memanfaatkan cahaya secaraefektif dan penyebaran unsur hara secara merata (Rukmana, 2005).

\section{Jumlah Daun per Tanaman (helai)}

Nilai rata-rata jumlah daun per tanaman dapat dilihat pada Tabel 2.Hasil analisis ragam menunjukkantidak terjadi interkasi antarakonsentrasi POC Azolla dan jaraktanam terhadap jumlah daun pertanaman sawi hijau, secara mandiripun tidak terdapat pengaruh yangberbeda nyata pada semua waktu umur pengamatan.

Tabel 2. Jumlah Daun per Tanaman (helai)

\begin{tabular}{|c|c|c|c|}
\hline Perlakuan & 14 HST & $21 \mathrm{HST}$ & $28 \mathrm{HST}$ \\
\hline $\mathrm{p}_{1}$ & $6,40 \mathrm{a}$ & $9,83 \mathrm{a}$ & $13,03 \mathrm{a}$ \\
\hline $\mathrm{p}_{2}$ & $6,73 \mathrm{a}$ & $10,13 \mathrm{a}$ & $13,48 \mathrm{a}$ \\
\hline $\mathrm{p}_{3}$ & $6,83 \mathrm{a}$ & $10,20 \mathrm{a}$ & $13,40 \mathrm{a}$ \\
\hline $\mathrm{p}_{4}$ & $6,78 \mathrm{a}$ & $9,95 \mathrm{a}$ & $13,63 \mathrm{a}$ \\
\hline $\mathrm{j}_{1}$ & $6,58 \mathrm{a}$ & $9,83 \mathrm{a}$ & $13,10 \mathrm{a}$ \\
\hline $\mathrm{j}_{2}$ & $6,68 \mathrm{a}$ & $10,08 \mathrm{a}$ & $13,58 \mathrm{a}$ \\
\hline $\mathrm{j}_{3}$ & $6,65 \mathrm{a}$ & $9,95 \mathrm{a}$ & $13,45 \mathrm{a}$ \\
\hline $\mathrm{j}_{4}$ & $6,83 \mathrm{a}$ & $10,25 \mathrm{a}$ & $13,40 \mathrm{a}$ \\
\hline
\end{tabular}


Keterangan :Angka rata-rata pada setiap kolom yang ditandai denganhuruf yang sama menunjukkan tidak berbeda nyata menurut Uji Lanjut Jarak berganda Duncan pada taraf 5\%.

Hasil analisis ragam perlakuanyang diuji menunjukkan tidakberbeda nyata pada semua stadia umur tanaman. Diduga pemberian POC Azolla sampai taraf perlakuan $\mathrm{p}_{4}$ belum mampu memberikanperbedaan bagi pembentukan jumlah daun. Sejalan dengan hasil penelitianDevia (2019) yang meneliti aplikasi pupuk organik cair azolla sampai konsentrasi $30 \%$ belum mampumeningkatkan pertumbuhan tanaman sawi hijau. Diduga penggunaankonsentrasi POC pada taraf percobaan terlalu sedikit mengandungunsur hara sehingga respon pada tanaman tidak terlihat. MenurutKusmanto (2010) untuk mencapai efisiensi pemupukan yang optimal, pupuk harus diberikan dalam jumlah yang mencukupi kebutuhan tanaman, tidak terlalu banyak dan tidak terlalu sedikit. Pemberian pupuk apabila terlalu sedikit pengaruhnya pada tanaman mungkin tidak akan tampak. Oleh karena itu hasil dari pemberian POC menjadi tidak berbeda nyata dantanaman hanya memanfaatkan unsur hara yang terkandung didalam tanah. Data pada Lampiran 3 menyajikan bahwa kandungan nitrogen tanah berada dikisaran sedang, phosfor sangat tinggi, dan kalium sangattinggi.

Hasil analisis ragam menunjukkantidak berbeda nyata pada semua tarafperlakuan jarak tanam umur 14, 21, dan 28 HST. Pertumbuhan tanaman sawi dilapangan masih belummencapai pertumbuhan maksimal, halini terlihat dari Tabel 1 tinggi tanaman hanya mencapai 28,07 cm sedangkan pada deskripsi taaman sawi hijau varietas kumala, pertumbuhannya mampu mencapai $33,3 \mathrm{~cm}$. Pertumbuhan yang tidak maksimal ini karena tidak dilakukan penambahan pupuk kimia ataupun pupuk organik padat dilahan. Pertumbuhan yang belum maksimal ini diduga membuat tidak terjadinya persaingan antar tanaman karena tajuk tidak terlalu padat. Gardner, dkk (1991) menyatakan bahwa kerapatan tanaman mempengaruhi pertumbuhantanamn yang disebabkan penyerapan energi matahari oleh permukaan daun, hal ini dapat menyebabkan terhambatnya perkembanganvegetatif dan menurunkan hasil panenakibat menurunnya laju fotosintesis dan perkembangan daun.

\section{Luas Daun per Tanaman $\left(\mathrm{cm}^{2}\right)$}

Nilai rata-rata luas daun per tanaman dapat dilihat pada Tabel 3. Hasil analisis ragam menunjukkan tidak terjadi interaksi antarakonsentrasi POC Azolla dan jarak tanam terhadap luas daun tanaman sawi hijau, secara mandiri pun tidak memberikan pengaruh yang berbeda nyata.

Hasil analisis ragam perlakuan yang diuji menunjukkan tidak berbeda nyata pengaruh konsentrasi Azolla pada berbagai taraf perlakuan.Hal ini sejalan dengan hasil analisis jumlah daun pada Tabel 2 yang menunjukkan hasil yang tidakberbeda nyata. Pupuk organik cair Azolla pada konsentrasi percobaan terlalu sedikit sehingga kandungan unsur haranya tidak berdampak pada pertumbuhan luas daun. Unsur hara yang paling berpengaruh pada daun adalah nitrogen. Menurut Harin dkk(2014) suplai nitrogen akan membuatbagian tanaman menjadi lebih hijau karena mengandung klorofil yangberperan 
dalam fotosintesis. Unsur tersebut juga bermanfaat untuk mempercepat pertumbuhan tinggi bagi tanaman, memperbanyak jumlahanakan, memengaruhi lebar danpanjang daun serta membuat menjadibesar, menambah kadar protein dan lemak bagi tanaman.

Tabel 3. Luas Daun $\left(\mathrm{cm}^{2}\right)$

\begin{tabular}{ll}
\hline \multicolumn{1}{c}{ Perlakuan } & $\begin{array}{c}\text { Luas Daun } \\
\left(\mathrm{cm}^{2}\right)\end{array}$ \\
\hline Konsentrasi POC & \\
Azolla & $1041,50 \mathrm{a}$ \\
$\mathrm{p}_{1}(0 \mathrm{ml} / \mathrm{l}($ kontrol $))$ & $1043,39 \mathrm{a}$ \\
$\mathrm{p}_{2}(5 \mathrm{ml} / \mathrm{l})$ & $1052,71 \mathrm{a}$ \\
$\mathrm{p}_{3}(10 \mathrm{ml} / \mathrm{l})$ & $1025,12 \mathrm{a}$ \\
$\mathrm{p}_{4}(15 \mathrm{ml} / \mathrm{l})$ & \\
\hline Jarak Tanam & $1035,70 \mathrm{a}$ \\
$\mathrm{j}_{1}(10 \mathrm{~cm} \times 10 \mathrm{~cm})$ & $1022,52 \mathrm{a}$ \\
$\mathrm{j}_{2}(10 \mathrm{~cm} \times 15 \mathrm{~cm})$ & $1051,15 \mathrm{a}$ \\
$\mathrm{j}_{3}(10 \mathrm{~cm} \times 20 \mathrm{~cm})$ & $1053,34 \mathrm{a}$ \\
$\mathrm{j}_{4}(10 \mathrm{~cm} \times 25 \mathrm{~cm})$ & \\
\hline
\end{tabular}

Keterangan : Angka rata-rata pada setiap kolom yang ditandai dengan hurufyang sama menunjukkan tidak berbeda nyata menurut Uji Lanjut Jarak Berganda Duncan pada taraf $5 \%$.

Rendahnya kandungan nitrogenpada konsentrasi POC Azolla menyebabkan tidak terlihatnya perbedaan yang nyata antar taraf perlakuan. Hal ini diperkuat dengan hasil penelitian Nafiadini (2019) pemberian POC Azolla pada berbagaikonsentrasi sampai 300 $\mathrm{ml} /$ liter tidak memberikan pengaruh yang nyata pada tanaman sawi. Serapan unsur hara bagi pertumbuhan sawi hanyadidapat dari kandungan nitrogen yangberada pada tanah. Kandungan unsur hara nitrogen yang berada dalam tanah pada kisaran sedang dan bersifat merata sehingga tidak terjadi perbedaan signifikan pada berbagaitaraf perlakuan.

Hasil analisis ragam jarak tanam terlihat tidak berbeda nyata padaberbagai taraf perlakuan. Hasil ini sejalan dengan Tabel 2 yaitu hasil analisis jumlah daun baik pada umur 14, 21, dan 28 HST. Diduga jaraktanam pada semua taraf perlakuan masih cukup optimal dengan kondisi pertumbuhan tanaman dilapangan sehingga tidak ada penurunan luas daun akibat dari terlalu banyaknya populasi

Menurut Djauhari el al (1987)Penambahan populasi tanaman akan meningkatkan hasil, tetapi bila populasi terus ditingkatkan hasil tanaman justru menurun, dengan demikian diperlukan suatu populasiyang optimum dari jarak tanam yang tepat untuk mencapai hasil yang maksimum dan tidak terjadi persaingan antar tanaman. Kondisi tanaman dilapangan memberikan kecukupan ruang tumbuh, sinarmatahari, dan juga unsur hara yang dibutuhkan tanaman masih dapat diserap dengan optimal pada semua taraf perlakuan sehingga menjadi tidak berbeda

nyata pada semua tarafperlakuan.

\section{Bobot Segar per Tanaman (g)}

Nilai rata-rata bobot segar per tanaman dapat dilihat pada Tabel 4. Hasil analisis 
ragam menunjukkan tidak terjadi interkasi antarakonsentrasi POC Azolla dan jarak tanam terhadap bobot segar tanaman sawi hijau, secara mandiri pun tidak memberikan pengaruh yang berbeda nyata.

Hasil analisis ragam perlakuan yang diuji menunjukkan tidakberbeda nyata pada berbagai taraf perlakuan konsentrasi POC Azolla. Hal ini sejalan dengan hasil analisis ragam jumlah daun dan luas daun.Diduga pemberian konsentrasi Azollabelum mampu meningkatkan hasil bobot segar per tanaman. Unsur hara yang diserap diduga hampir seluruhnya disuplai dari kandunganpada tanah.

Konsentrasi POC Azolla dilahanpercobaan tertinggi dilakukan pada konsentrasi 15 $\mathrm{ml} / \mathrm{L}$. Konsentrasi tersebut diduga masih terlalu sedikit, penelitian lain yaitu Nurul (2019) melakukan percobaan konsentrasi POC Azolla terbaik pada tanaman bayam merah adalah sebesar $75 \mathrm{ml} / \mathrm{l}$, sehingga penggunaan POC yang dilakukan masih terlalu rendah konsentrasinya dan menyebabkantidak berbeda nyata.

\section{Tabel 4. Bobot Segar per Tanaman (g)}

\begin{tabular}{lc}
\hline \multicolumn{1}{c}{ Perlakuan } & Bobot Segarper Tanaman $(\mathrm{g})$ \\
\hline Konsentrasi POC Azolla & \\
$\mathrm{p}_{1}(0 \mathrm{ml} / \mathrm{l}($ kontrol$))$ & $74,13 \mathrm{a}$ \\
$\mathrm{p}_{2}(5 \mathrm{ml} / \mathrm{l})$ & $77,45 \mathrm{a}$ \\
$\mathrm{p}_{3}(10 \mathrm{ml} / \mathrm{l})$ & $76,63 \mathrm{a}$ \\
$\mathrm{p}_{4}(15 \mathrm{ml} / \mathrm{l})$ & $75,50 \mathrm{a}$ \\
\hline $\mathrm{Jarak}$ Tanam & \\
$\mathrm{j}_{1}(10 \mathrm{~cm} \times 10 \mathrm{~cm})$ & $74,93 \mathrm{a}$ \\
$\mathrm{j}_{2}(10 \mathrm{~cm} \times 15 \mathrm{~cm})$ & $74,90 \mathrm{a}$ \\
$\mathrm{j}_{3}(10 \mathrm{~cm} \times 20 \mathrm{~cm})$ & $77,23 \mathrm{a}$ \\
$\mathrm{j}_{4}(10 \mathrm{~cm} \times 25 \mathrm{~cm})$ & $76,65 \mathrm{a}$ \\
\hline
\end{tabular}

Keterangan : Angka rata-rata pada setiap kolom yang ditandai dengan huruf yang sama menunjukkan tidak berbeda nyata menurut Uji Lanjut Jarak Berganda Duncan pada taraf 5\%.

Hasil analisis ragam menunjukkan tidak berbeda nyata taraf perlakuan jarak tanam. Hal ini sejalan dengan hasil analisis jumlah daun dan luas daun. Diduga jarak tanam yang digunakan masih mencukupi bagipertumbuhan tanaman sawi hijau.Menurut Suprapto (1992) Salah satu usaha untuk meningkatkan produktivitas tanaman yaitu dengan mengatur jarak tanam atau kepadatan tanaman per satuan luas sehingga tidak terjadi persaingan antar tanaman. Jarak tanam yang mencukupi bagi pertumbuhan sawi hijau menyebabkan tidak terjadinya persaingan kebutuhan hidup seperticahaya matahari, air, dan unsur hara sehingga tidak berbeda nyata.

\section{Bobot Segar Akar per Tanaman (g)}

Nilai rata-rata bobot segar akar per tanaman dapat dilihat pada Tabel 5. Hasil analisis ragam menunjukkan tidak terjadi interkasi antarakonsentrasi POC Azolla dan jarak tanam terhadap bobot segar akartanaman sawi hijau, secara mandiri pun tidak memberikan pengaruh yangberbeda nyata. 
Hardjowigeno (2003) menyatakan unsur fosfor sangat berguna untuk merangsang pertumbuhan akar, bahandasar protein, proses fotosintesis, memperkuat batang tanaman serta membantu asimilasi dan respirasi.

Unsur P pada tanah sangat dipengaruhi oleh $\mathrm{pH}$ tanah. Menurut Andy dan Abdullah (2004) Tingkat kemasaman $(\mathrm{pH})$ tanah, selain mempunyai pengaruh langsung terhadap tanaman, juga berpengaruh terhadap pola ketersediaan unsur hara. Pada tanah masam, kandungan hara $\mathrm{P}$ berkorelasi negatif dengan $\mathrm{Al}$ dan $\mathrm{Fe}$, di mana semakin tinggi kandungan $\mathrm{Al}$ atau $\mathrm{Fe}$ dalam tanah maka semakin rendah kandungan P tersedia (Nasution dan Al-Jabri 1999).

Tabel 5. Bobot Segar Akar per Tanaman (g)

\begin{tabular}{lc}
\hline \multicolumn{1}{c}{ Perlakuan } & Bobot SegarAkar per Tanaman $(\mathrm{g})$ \\
\hline Konsentrasi POC & \\
Azolla & \\
$\mathrm{p}_{1}(0 \mathrm{ml} / \mathrm{l}(\mathrm{kontrol}))$ & $8,33 \mathrm{a}$ \\
$\mathrm{p}_{2}(5 \mathrm{ml} / \mathrm{l})$ & $7,88 \mathrm{a}$ \\
$\mathrm{p}_{3}(10 \mathrm{ml} / \mathrm{l})$ & $8,73 \mathrm{a}$ \\
$\mathrm{p}_{4}(15 \mathrm{ml} / \mathrm{l})$ & $8,93 \mathrm{a}$ \\
\hline Jarak Tanam & \\
$\mathrm{j}_{1}(10 \mathrm{~cm} \times 10 \mathrm{~cm})$ & $8,38 \mathrm{a}$ \\
$\mathrm{j}_{2}(10 \mathrm{~cm} \times 15 \mathrm{~cm})$ & $8,38 \mathrm{a}$ \\
$\mathrm{j}_{3}(10 \mathrm{~cm} \times 20 \mathrm{~cm})$ & $8,65 \mathrm{a}$ \\
$\mathrm{j}_{4}(10 \mathrm{~cm} \times 25 \mathrm{~cm})$ & $8,45 \mathrm{a}$ \\
\hline
\end{tabular}

Keterangan : Angka rata-rata pada setiap kolom yang ditandai dengan huruf yang sama menunjukkan tidak berbeda nyata menurut Uji Lanjut Jarak Berganda Duncan pada taraf 5\%.

Tanah masam merupakan tanah yang didominasi mineral-mineral kaolinit, oksida besi danaluminium, serta kandungan $\mathrm{Al}$ yang semakin meningkat pada lapisan tanah bawah (Hairiah et al. 2000). Bentuk $\mathrm{Al}$ yang beracun bagi akar tanaman adalah Almonomerik, yaitu $\mathrm{Al}_{3}{ }^{+} . \mathrm{Al}\left(\mathrm{OH}_{2}{ }^{+}, \mathrm{Al}\left(\mathrm{OH}_{2}{ }^{+}, \mathrm{Al}\left(\mathrm{OH}_{3}{ }^{+}\right.\right.\right.$, dan $\mathrm{Al}(\mathrm{SO} 4)^{+}$. Aktivitas $\mathrm{Al}-$ monomerik semakin meningkat pada $\mathrm{pH}$ lebih rendah dari 5,5 dan keracunan $\mathrm{Al}$ ini akan semakin meningkat dengan meningkatnya kandungan mineral liat silikat 2:1 (Andy dan Abdullah, 2004). Sedangkan hasil analisis tanah $\mathrm{pH}$ pada lahan percobaan termasuk pada kategori netral sehingga serapan unruP untuk membentuk perakaran dapat diserap lebih maksimal dan menjadikan tidak berbeda nyatanya perlakuan.

\section{Bobot Kering per Tanaman (g)}

Nilai rata-rata bobot kering per tanaman dapat dilihat pada Tabel 6. Hasil analisis ragam menunjukkan tidak terjadi interkasi antarakonsentrasi POC Azolla dan jarak tanam terhadap bobot kering tanamansawi hijau, secara mandiri pun tidak memberikan pengaruh yang berbeda nyata.

Hasil analisis ragam menunjukkantidak berbeda nyata berbagai taraf perlakuan konsentrasi maupun jarak tanam pada tanaman sawi hijau. Hal ini sejalan dengan hasil analisis ragamjumlah daun, luas daun, berat segar pertanaman, dan berat segar akar pertanaman. Diduga tidak berbeda nyatanya perlakuan akibat dari suplaiunsur hara yang didapat hanya dari kandungan unsur hara pada tanah saja, penambahan unsur hara dari 
POC terlalu sedikit dan jarak tanam rapatpun menjadikan persainganunsur hara tidak terlalu berpengaruh. Jumlah unsur hara yang relatif sama membuat pertumbuhan tanaman seragam sehingga bobot kering menjadi tidak berbeda nyata. Bobot kering merupakan hasil dari ikatankarbon akibat fotosintesis oleh tanaman. Sesuai pernyataan Gardner et al (1991) Hasil berat kering merupakan keseimbangan antara fotosintesis dan respirasi. Fotosintesis mengakibatkan peningkatan berat kering tanaman karena pengambilan $\mathrm{CO}_{2}$ sedangkan respirasi mengakibatkan penurunan berat kering karena pengeluaran $\mathrm{CO}_{2}$.

Tabel 6. Bobot Kering per Tanaman (g)

\begin{tabular}{|c|c|}
\hline Perlakuan & Bobot Kering per Tanaman $(\mathrm{g})$ \\
\hline \multicolumn{2}{|l|}{ Konsentrasi POC } \\
\hline \multicolumn{2}{|l|}{ Azolla } \\
\hline $\mathrm{p}_{1}(0 \mathrm{ml} / \mathrm{l}(\mathrm{kontrol}))$ & $14,28 \mathrm{a}$ \\
\hline $\mathrm{p}_{2}(5 \mathrm{ml} / \mathrm{l})$ & $16,38 \mathrm{a}$ \\
\hline $\mathrm{p}_{3}(10 \mathrm{ml} / \mathrm{l})$ & $15,63 \mathrm{a}$ \\
\hline $\mathrm{p}_{4}(15 \mathrm{ml} / \mathrm{l})$ & $15,13 \mathrm{a}$ \\
\hline \multicolumn{2}{|l|}{ Jarak Tanam } \\
\hline $\mathrm{j}_{1}(10 \mathrm{~cm} \times 10 \mathrm{~cm})$ & $15,38 \mathrm{a}$ \\
\hline $\mathrm{j}_{2}(10 \mathrm{~cm} \times 15 \mathrm{~cm})$ & $15,15 \mathrm{a}$ \\
\hline $\mathrm{j}_{3}(10 \mathrm{~cm} \times 20 \mathrm{~cm})$ & $15,75 \mathrm{a}$ \\
\hline $\mathrm{j}_{4}(10 \mathrm{~cm} \mathrm{x} 25 \mathrm{~cm})$ & $15,13 \mathrm{a}$ \\
\hline
\end{tabular}

\section{Bobot Kering Akar per Tanaman (g)}

Nilai rata-rata bobot kering akar per tanaman dapat dilihat pada Tabel 7. Hasil analisis ragam menunjukkantidak terjadi interkasi antarakonsentrasi POC Azolla dan jarak tanam terhadap bobot kering akar tanaman sawi hijau, secara mandiri pun tidak memberikan pengaruh yangberbeda nyata.

Tabel 7. Bobot Kering Akar per Tanaman (g)

\begin{tabular}{lc}
\hline \multicolumn{1}{c}{ Perlakuan } & Bobot KeringAkar per Tanaman $(\mathrm{g})$ \\
\hline Konsentrasi POC & \\
Azolla & $2,05 \mathrm{a}$ \\
$\mathrm{p}_{1}(0 \mathrm{ml} / \mathrm{l}(\mathrm{kontrol}))$ & $2,30 \mathrm{a}$ \\
$\mathrm{p}_{2}(5 \mathrm{ml} / \mathrm{l})$ & $2,23 \mathrm{a}$ \\
$\mathrm{p}_{3}(10 \mathrm{ml} / \mathrm{l})$ & $2,55 \mathrm{a}$ \\
$\mathrm{p}_{4}(15 \mathrm{ml} / \mathrm{l})$ & \\
\hline $\mathrm{Jarak} \mathrm{Tanam}^{\mathrm{j}}$ & \\
$\mathrm{j}_{1}(10 \mathrm{~cm} \times 10 \mathrm{~cm})$ & $1,98 \mathrm{a}$ \\
$\mathrm{j}_{2}(10 \mathrm{~cm} \times 15 \mathrm{~cm})$ & $2,25 \mathrm{a}$ \\
$\mathrm{j}_{3}(10 \mathrm{~cm} \times 20 \mathrm{~cm})$ & $2,48 \mathrm{a}$ \\
$\mathrm{j}_{4}(10 \mathrm{~cm} \times 25 \mathrm{~cm})$ & $2,43 \mathrm{a}$ \\
\hline
\end{tabular}

Keterangan : Angka rata-rata pada setiap kolom yang ditandai denganhuruf yang sama 
menunjukkan tidak berbeda nyata menurut Uji Lanjut Jarak Berganda Duncan padataraf 5\%.

Hasil analisis ragam perlakuanyang diuji yaitu bobot kering akar pertanaman terlihat tidak berbeda nyata pada berbagai taraf perlakuan. Hal inisejalan dengan hasil analisis ragam jumlah daun, luas daun, bobot basah pertanaman, dan bobot kering tanaman. Serapan hara yang relatifsama dari kandungan unsur hara tanahmenjadikan pertumbuhan tanaman relatif seragam, $\mathrm{pH}$ tanah yang netralpun membuat unsur hara pada tanah berada pada kondisi tersedia dan berat kering akar menjadi tidak berbeda nyata.

Sitompul dan Guritno, 1995 menyatakan bahwa perhitungan beratkering tanaman penting dilakukan, karena berat kering digunakan untuk melihat metabolisme tanaman. Berat kering dapat mewakili hasil metabolittanaman karena didalam daun dan organ lain mengandung hasil metabolit. Pertambahan berat kering digunakan sebagai indikator pertumbuhan tanaman karena beratkering mencerminkan akumulasi senyawa organik yang berhasil disintesis tanaman dari senyawa anorganik yaitu air dan $\mathrm{CO}_{2}$.

Menurut Larcher (1975) berat kering tanaman merupakan hasil penimbunan bersih asimilasi $\mathrm{CO}_{2}$ yang dilakukan selama pertumbuhan dan perkembangan tanaman. Pertumbuhan tanaman adalah suatu peningkatan berat segar dan penimbunan bahan kering. Jadi semakin baik pertumbuhan tanaman maka berat kering juga semakin meningkat.

\section{Nisbah Pupus Akar}

Nilai rata-rata nisbah pupus akar per tanaman dapat dilihat pada Tabel 8. Hasil analisis ragam menunjukkantidak terjadi interkasi antarakonsentrasi POC Azolla dan jarak tanam terhadap nisbah pupus akar tanaman sawi hijau, secara mandiri pun tidak memberikan pengaruh yangberbeda nyata.

Tabel 8. Bobot Nisbah Pupus Akar

\begin{tabular}{lc}
\hline \multicolumn{1}{c}{ Perlakuan } & Nisbah Pupus Akar \\
\hline Konsentrasi POC & \\
Azolla & \\
$\mathrm{p}_{1}(0 \mathrm{ml} / \mathrm{l}$ (kontrol) & $7,16 \mathrm{a}$ \\
) $\mathrm{p}_{2}(5 \mathrm{ml} / \mathrm{l})$ & $7,56 \mathrm{a}$ \\
$\mathrm{p}_{3}(10 \mathrm{ml} / \mathrm{l})$ & $7,34 \mathrm{a}$ \\
$\mathrm{p}_{4}(15 \mathrm{ml} / \mathrm{l})$ & $6,03 \mathrm{a}$ \\
\hline Jarak Tanam & \\
$\mathrm{j}_{1}(10 \mathrm{~cm} \times 10 \mathrm{~cm})$ & $8,01 \mathrm{a}$ \\
$\mathrm{j}_{2}(10 \mathrm{~cm} \times 15 \mathrm{~cm})$ & $6,95 \mathrm{a}$ \\
$\mathrm{j}_{3}(10 \mathrm{~cm} \times 20 \mathrm{~cm})$ & $6,60 \mathrm{a}$ \\
$\mathrm{j}_{4}(10 \mathrm{~cm} \times 25 \mathrm{~cm})$ & $6,52 \mathrm{a}$ \\
\hline
\end{tabular}

Keterangan : Angka rata-rata pada setiap kolom yang ditandai dengan huruf yang sama menunjukkan tidak berbeda nyata menurut Uji Lanjut Jarak Berganda Duncan pada taraf $5 \%$.

Hasil analisis ragam perlakuanyang diuji terlihat tidak berbeda nyatapada berbagai 
taraf perlakuan NPA. Hal ini sejalan dengan hasil analisis ragam jumlah daun, luas daun, bobot basah pertanaman, bobot keringpertanaman, dan bobot kering akarpertanaman. Diduga kandungan unsurhara ditunjang $\mathrm{pH}$ yang baik menjadikan cukup tersedia bagi pertumbuhan tanaman. Hasil analisis ragam terlihat cukup banyak pertumbuhan tanaman kebagian atas atau tajuk tanaman.

Kadar N yang cukup menyebabkannilai NPA tinggi, sementara nilai N yang rendah menyebabkan nilai NPAmenjadi rendah. Menurut Darmawan dan Baharsjah (2010) hal ini disebabkan karena nitrat $(\mathrm{N})$ yang diserap oleh akar segera dipergunakan untuk pembentukan asam amino dalam akar. Bersama- sama dengan karbohidrat yang turun dari daun, terbentuklah protein untukpertumbuhan akar. Karena bila kadarN tanah rendah, perbandingan NPA menjadi rendah, atau akar relatiftumbuh lebih besar dari pada pucuk.

Hasil NPA berbanding lurus dengan pengamatan luas daun, semakin tinggi luas daun maka akan menambah bobot pupus tanaman,semakin besar luas daun semakin besar nilai NPA. Kemudian Darmawan dan Baharsjah (2010) menambahkan karena pertumbuhan vegetatif yang pesat, maka karbohidrat yang di angkut ke akar relatif sedikit. Oleh karena itudibandingkan dengan daun, akar menderita kekurangan karbohidrat dan protein sehingga pertumbuhan akar lebih lambat dari padapertumbuhan daun. Dengan demikianmaka nisbah pupus akar menjadi tinggi.

\section{Hasil Segar per Plot}

Nilai rata-rata hasil segar per plot dapat dilihat pada Tabel 9. Hasil analisis ragam menunjukkan tidak terjadi interkasi antara konsentrasi POC Azolla dan jarak tanam terhadaphasil segar per plot tanaman sawi hijau, namun secara mandiri dapat memberikan pengaruh yang berbeda nyata. Faktor perlakuan konsentrasi POC Azolla pada taraf $\mathrm{p}_{4}$ dan faktor jarak tanam $\mathrm{j}_{4}$ memberikan pengaruh yang berbeda nyata dibandingkan taraf perlakuan lainnya.

Tabel 9. Hasil Segar per Plot (g)

\begin{tabular}{ll}
\hline \multicolumn{1}{c}{ Perlakuan } & Hasil Segar per Plot $(\mathrm{g})$ \\
\hline Konsentrasi POC & \\
Azolla & \\
$\mathrm{p}_{1}(0 \mathrm{ml} / \mathrm{l}($ kontrol $))$ & $1745,38 \mathrm{a}$ \\
$\mathrm{p}_{2}(5 \mathrm{ml} / \mathrm{l})$ & $1861,38 \mathrm{a}$ \\
$\mathrm{p}_{3}(10 \mathrm{ml} / \mathrm{l})$ & $1882,75 \mathrm{a}$ \\
$\mathrm{p}_{4}(15 \mathrm{ml} / \mathrm{l})$ & $2009,88 \mathrm{~b}$ \\
\hline Jarak Tanam & \\
$\mathrm{j}_{1}(10 \mathrm{~cm} \times 10 \mathrm{~cm})$ & $1752,50 \mathrm{a}$ \\
$\mathrm{j}_{2}(10 \mathrm{~cm} \times 15 \mathrm{~cm})$ & $1846,38 \mathrm{a}$ \\
$\mathrm{j}_{3}(10 \mathrm{~cm} \times 20 \mathrm{~cm})$ & $1882,63 \mathrm{a}$ \\
$\mathrm{j}_{4}(10 \mathrm{~cm} \times 25 \mathrm{~cm})$ & $2017,88 \mathrm{~b}$ \\
\hline
\end{tabular}

Keterangan : Angka rata-rata pada setiap kolom yang ditandai dengan huruf yang sama menunjukkan tidak berbeda nyata menurut Uji Lanjut Jarak Berganda Duncan pada taraf5\%.

Hasil analisis ragam perlakuanyang diuji yaitu rata-rata berat segar perplot terlihat berbeda nyata padataraf perlakuan konsentrasi POC Azolla $\mathrm{p}_{1}, \mathrm{p}_{2}, \mathrm{p}_{3}$ dibanding taraf 
perlakuan $\mathrm{p}_{4}$. hal yang sama terjadi pada taraf perlakuan jarak tanam berbeda nyata pada taraf perlakuan $\mathrm{j}_{1} \mathrm{j}_{2}, \mathrm{j}_{3}$, dibanding taraf perlakuan $\mathrm{j}_{4}$. Hasil segar plot berbeda dengan hasil segar pertanaman yang menunjukkanhasil yang tidak berbeda nyata. Diduga serangan OPT ulat daun padasawi hijau menyebabkan terjadinyaperbedaan berat segar dalam satuan plot sehingga hasil berat segar menjadi tidak berbeda nyata.

Ulat yang cukup banyak menyerang tanaman sawi hijau di lapangan adalah Plutella xylostella. Serangan ulat plutella pada tanaman sawi sebesar $16,33 \%$ dan termasukedalam kategori ringan (0-25\%, Ayu dkk (2019)). Serangan ulat plutella memakan jaringan daun tanaman sawi sehingga terjadi perlambatan pada pertumbuhan tanaman. Diduga perlambatan pertumbuhan ini menjadikan taraf perlakuan $\mathrm{p}_{4}$ dan $\mathrm{j}_{4}$ menjadi berbeda nyata dibanding taraf perlakuan yang lainnya.

\section{Kesimpulan}

Berdasarkan hasil penelitian dapatditarik kesimpulan sebagai berikut :

1. Tidak terjadi interaksi antara berbagai konsentrasi POC Azolla dan jarak tanam terhadap pertumbuhan dan hasil sawi hijau.

2. Pengaruh mandiri konsentrasiPOC Azolla $15 \mathrm{ml} / \mathrm{l}$ danperlakuan jarak tanam 10 $\mathrm{cm} \times 25 \mathrm{~cm}$ dapat memberikan rata-rata tertinggi pada parameter pengamatan tinggi tanaman umur28 HST dan bobot segar tanamanper plot.

\section{Daftar Pustaka}

Andy W., dan A. Taufiq. 2004.Pengelolaan Kesuburan Lahan Kering Masam untuk Tanaman Kedelai. Peneliti Ekofisiologi Balai Penelitian Tanaman Kacangkacangandan Umbi-umbian. Buletin Palawija No. 7 \& 8: 39-50.

Ayu N.S.A Lumban Gaol,H.L.Rampe, M. Rumondor. 2019. Intensitas Serangan Akibat Hama Pemakan Daun Setelah Aplikasi EkstrakDaun Babadotan (Ageratum conyzoides L.) Pada TanamanSawi (Brassica juncea L.). Jurnal Ilmiah Sains Vol. $19: 2$.

Darmawan, J. dan J.S. Baharsjah. 2010. Dasar-dasar FisiologiTanaman. SITC. Jakarta.

Devia P.G. 2019. Pengaruh Konsentrasi Pupuk Organik Cair Azolla dan Dosis Pupuk Kascing TerhadapPertumbuhan dan Produksi Tanaman Pakcoy (Brassicarappa L). Skripsi. UniversitasJenderal Soedirman. Fakultas Pertanian Purwokerto.

Djauhari, A., M. Syani, A. Malian dan M.G. Van Der Veen. 1987.Latihan Metode Penelitian Teknik Budidaya Tanaman Pangan dan Industri. Badan Penelitian dan

PengembanganPertanian. Nusa Tenggara.

Dhiya S, Sampurno dan E. Anom. UjiBeberapa Konsentrasi Pupuk Cair Azolla (Azolla pinnata) pada Pertumbuhan Bibit Kelapa Sawit (Elaeis guineensis Jacq.) di Pembibitan Utama. Jom Faperta. Vol. 2 No.1.

Gardner, F. P. Pearce. R. B. and Michell. R. L. 1996.Physiology of Crop Plant.Terjemahan Herawati, Susilo,dan Subiyanto. UI Pres, Jakarta.

Gunawan, S. S. 2013. Pengaruh Konsentrasi Urine Sapi Dengan Dua Interval Penyemprotan terhadapPertumbuhan Tanaman SawiHijau (Brassica juncea L.). Skripsi. Fakultas Pertanian dan Peternakan UniversitasIslam Negeri Sultan Syarif Kasim Riau, Pekanbaru.

Hairiah, K., S. R. Utami, D.Suprayogo, D. Widianto, S.M. Sitompul, Sunaryo, B. B. 
Lusiana, R. Mulia, M. Van Nordwijk, dan G. Cadisch. 2000. Agroforestri pada Tanah Masam di Daerah Tropika Basah: Pengelolaan Interaksi antara Pohon Tanaman Semusim. International Centre for Research in Agroforestry (ICRAF). Bogor.

Harin E.P, T. Wardiyati dan M. Nawawi. 2016. Pengaruh Dosis Pupuk Nitrogen dan Tingkat Kepadatan Tanaman terhadap Pertumbuhan dan Hasil Tanaman Kailan (Brassica oleraceae L.). Jurnal Produksi Tanaman, Vol 4 : 1.

Hardjowigeno, S. 2003. Klasifikasi Tanah dan Pedogenesis. Akademika Pressindo.

Jakarta.

Haryadi, S.S. 1988. Pengantar Agronomi. Gramedia. Jakarta.

Haryanto, E., T. Suhartini, E. Rahayu. 2003. Sawi hijau danSalada. Penebar Swadaya. Jakarta.

Kusmanto, A.F, Aziez dan T. Soemarah. 2010. Pengaruh Dosis Pupuk Nitrogen dan Pupuk Kandang Kambingterhadap Pertumbuhan dan Hasil Jagung Hibrida (Zeamays L.) Varitas Pioneer 21.J. Agrineca. 10: 135- 150.

Larcher, W. 1975. Physiological Plant Ecology : Ecophysiology and Stress Physiology of Functional Groups. Third Edition. Springer. New York.

Nasution, I. dan M. Al-Jabri. 1999. Hubungan Hasil TanamanKedelai dengan Pemupukan Ppada Beberapa Status P Tanahyang Berbeda Berdasarkan Jerapan P Tanah pada tanah Ultisol Lampung. Disampaikan pada Seminar Nasional Sumber Daya Tanah, Iklim dan Pupuk. Pusat Penelitian Tanah dan Agroklimat. Bogor.

Nurlaeny, N. 2015. Bahan Organik Tanah dan Dinamika Ketersediaan Unsur Hara Tanaman. UNPAD Press.Bandung

Rajiman. 2020. Pengantar Pemupukan. CV. Budi Utama.Yogyakarta.

Rukmana. 2005. Bertanam Kubis. Kanisius. Yogyakarta. . 2007. Bertanam Petsai danSawi hijau. Kanisius. Yogyakarta.

Sitompul , S.M. dan B. Guritno, 1995. Analisis Pertumbuhan Tanaman. Gadjah Mada University Press. Yogyakarta.

Suprapto J. 1992. Teknik SamplingUntuk Survey dan Eksperimen, Rinika Cipta. Jakarta.

Syafruddin, R. Faesal dan M. Akil. 2009. Pupuk dan Pemanfaatan Bagi Tanaman. Bumi Aksara, Yogyakarta.

Warsa T. dan Achyar C.S. 1982. Teknik Perancangan Percobaan Percobaan Serial Pengenalan Dasar StatistikaTerapan. Universitas Padjadjaran, Bandung. 